\title{
Development of in situ hybridization and RT-PCR assay for the detection of a nodavirus ( $P V N V)$ that causes muscle necrosis in Penaeus vannamei
}

\author{
Kathy F. J. Tang*, Carlos R. Pantoja, Rita M. Redman, Donald V. Lightner \\ Department of Veterinary Science and Microbiology, University of Arizona, 1117 East Lowell Street, Tucson, \\ Arizona 85721, USA
}

\begin{abstract}
A nodavirus (tentatively named $P V N V$, Penaeus vannamei nodavirus) that causes muscle necrosis in P. vannamei was found in Belize in 2004. From 2004 to 2006, shrimp samples collected from Belize exhibited clinical signs, white, opaque lesions in the tails and histopathology similar to those of shrimps infected by infectious myonecrosis virus (IMNV). Histological examination revealed multifocal necrosis and hemocytic fibrosis in the skeletal muscle. In addition, basophilic, cytoplasmic inclusions were found in striated muscle, lymphoid organ and connective tissues. However, IMNV was not detected in these shrimps by either RT-PCR or in situ hybridization, suggesting that these lesions may be caused by another RNA virus. Thus, a cDNA library was constructed from total RNA extracted from hemolymph collected from infected shrimp. One clone (designated $P V N V-4$ ) with a $928 \mathrm{bp}$ insert was sequenced and found to be similar (69\% similarity when comparing the translated amino acid sequences) to the capsid protein gene of MrNV (Macrobrachium rosenbergii nodavirus). The insert of $P V N V-4$ was labeled with digoxigenin-11-deoxyuridine triphosphate (dUTP) and hybridized to tissue sections of $P$. vannamei with muscle necrosis collected in Belize and from laboratory bioassays. The samples were positive for $P_{V N V}$ infection. Positively reacting tissues included skeletal muscle, connective tissues, the lymphoid organ, and hemocytes in the heart and gills. In addition, we experimentally infected both $P$. vannamei and $P$. monodon with $P V N V$ prepared from Belize samples. A nested RT-PCR assay developed from the $P_{V N V}-4$ cloned sequence showed that both species are susceptible to $P_{V} \mathrm{NV}$ infection.
\end{abstract}

KEY WORDS: Penaeus vannamei nodavirus ' In situ hybridization · RT-PCR $\cdot$ Penaeus monodon

\section{INTRODUCTION}

Muscle necrosis in shrimp often results in the appearance of white and opaque lesions in the tail muscle in response to environmental factors, such as sudden changes in temperature, salinity, or other stress (Lightner 1988). Shrimp culture techniques have greatly improved in recent years and stress-related muscle necrosis is now quickly identified and properly managed to reduce production losses. During the past few years, virus infection has also been found to cause muscle necrosis in cultured shrimp. An example is $\mathrm{MrNV}$ (Macrobrachium rosenbergii nodavirus) infection in freshwater prawns (Arcier et al. 1999, Qian et al. 2003, Bonami et al. 2005, Shekhar et al. 2006), causing a disease referred to as white tail disease. Another virus that infects marine shrimp is IMNV (infectious myonecrosis virus) (Poulos et al. 2006). Both viral infections lead to mortalities, up to $100 \%$ from $\mathrm{MrNV}$ infection and 20 to $60 \%$ for IMNV (Nunes et al. 2004, Tang et al. 2005).

In 2004, another virus that causes muscle necrosis was found in Penaeus vannamei cultured in Belize. Infection with this virus resulted in a $50 \%$ reduction in production in some ponds at the affected farm. Through cDNA synthesis, cloning and sequencing, we identified the virus as a nodavirus that is related to 
MrNV. To provide diagnostic tools, we have developed an in situ hybridization method and a nested RT-PCR assay which are specific for $P$. vannamei nodavirus $(P V N V)$.

\section{MATERIALS AND METHODS}

Shrimp, PVNV isolate, generation of inoculum and infected tissues. Shrimp taxonomy was according to Holthius (1980). The PvNV-infected tissues used in this study was obtained in 2005 in Belize from farmraised Penaeus vannamei that were exhibiting signs of muscle necrosis. The inoculum was made from the heads of these shrimp, which were stored frozen at $-70^{\circ} \mathrm{C}$ at the University of Arizona. Soft tissues were minced, homogenized in TN buffer $(20 \mathrm{mM}$ Tris- $\mathrm{HCl}$, $400 \mathrm{mM} \mathrm{NaCl}, \mathrm{pH}$ 7.4), and clarified by centrifugation at $3000 \times g$ for $30 \mathrm{~min}$. The tissue homogenate was aliquoted and stored at $-70^{\circ} \mathrm{C}$. Prior to injection, the tissue homogenate was diluted (v/v 1:20) with $2 \%$ saline, filtered through a $0.45 \mu \mathrm{m}$ membrane, and injected into the muscle of specific-pathogen-free (SPF) P. vannamei Kona stock, Oceanic Institute, Hawaii, Wyban et al. 1992). To generate the infected tissues for feeding experiments, the inoculated shrimp were maintained in seawater at 26 to $28^{\circ} \mathrm{C}$ for $4 \mathrm{wk}$. At termination, shrimp were collected and stored at $-70^{\circ} \mathrm{C}$. Samples of the cephalothoraces were fixed in Davidson's alcohol formalin acetic acid (AFA) fixative for $24 \mathrm{~h}$, then changed to $70 \%$ ethanol according to the procedures of Bell \& Lightner (1988). Paraffin sections were stained with Mayer-Bennet haematoxylin and eosin-phloxine (H\&E). Histological examination was used to confirm that shrimp were infected with $P V N V$ only. Shrimp sampled for electron microscopic study were preserved in $6 \%$ phosphate-buffered glutaraldehyde and processed for examination as described in Bonnami et al. (1992). The sections were mounted on the grids and examined under a Philips CM12 electron microscope.

Since 2004, shrimp with white tails have been collected from the Belize farm, fixed in Davidson's AFA solution and sent to our laboratory. These samples were processed for H\&E staining and histological examination.

Experimental infection of $P v N V$ in Penaeus vannamei and $P$. monodon. Two species of penaeid shrimp were used for the experimental infection study, viz. SPF P. vannamei (Kona stock, Oceanic Institute) and P. monodon (Moana Technologies, Hawaii; shrimp were tested at our laboratory and demonstrated to be free of the major shrimp pathogens listed by the Office International des Epizooties). For the injection study, 20 individuals of each species (2 g mean weight) were injected with a $P V N V$ inoculum as described above. A volume of $100 \mu \mathrm{l}$ of inoculum was injected into each shrimp. They were then maintained on a pelletized ration (Rangen 35\%) for $4 \mathrm{wk}$. At the end of the bioassay, shrimp were sampled for histological examination, in situ hybridization analysis and RT-PCR (Table 1). For the time-course study of $P$. monodon, 15 shrimp ( $2 \mathrm{~g}$ mean weight) were injected with $P v N V$ inoculum, then maintained on a pelletized ration. Two shrimp were sacrificed at each time point (2 h, Days 1, 2, 3, 5, 10 and 15), and hemolymph and pleopods were sampled for RNA extraction with a High Pure RNA tissue kit (Roche) followed by RT-PCR analysis.

For per os infection, 20 Penaeus vannamei (0.1 g mean weight) and $30 \mathrm{P}$. monodon ( $0.1 \mathrm{~g}$ mean weight) individuals were fed minced $P V N V$-infected tissues, generated as described above, at $10 \%$ of total body weight once daily for $5 \mathrm{~d}$. Thereafter, the shrimp were maintained on a pelletized ration for $4 \mathrm{wk}$. At the end of the bioassay, shrimp were sampled for nested RTPCR analysis (Table 1).

Synthesis and cloning of PVNV cDNA. Total RNA was extracted from the hemolymph of $P V N V$-infected shrimp using TRIzol LS (Invitrogen). These shrimp were generated through injection infection as described above. The cDNA was synthesized using the SuperScript Choice system (Invitrogen) and ligated into pSport 1 (Invitrogen) plasmid. The recombinant plasmids were transformed into competent Escherichia coli DH5 $\alpha$ cells, and clones containing cDNA inserts were selected by colony-PCR with the procedure described by Tang et al. (2005). PCR amplicons were purified and then sequenced at the University of Arizona sequencing facility.

Probe labeling and in situ hybridization. One cDNA clone $(P v N V-4)$ with a 928 bp insert (GenBank acces-

Table 1. Penaeus vannamei and P. monodon. Histological examination, in situ hybridization (ISH) and nested RT-PCR detection of $P$. vannamei nodavirus $(P V N V)$ in laboratory challenged shrimp

\begin{tabular}{|c|c|c|}
\hline \multirow{2}{*}{ Method of challenge } & \multirow{2}{*}{\multicolumn{2}{|c|}{$\begin{array}{rr} & P V N V \text { infection }- \\
\text { Histology/ISH } & \text { RT-PCR }\end{array}$}} \\
\hline & & \\
\hline \multicolumn{3}{|l|}{ P. vannamei } \\
\hline Injection & Positive/Positive & Positive (1-step, 9/9a) \\
\hline Per os & Not done & Positive (1- and 2-step, $3 / 5^{a}$ ) \\
\hline \multicolumn{3}{|l|}{ P. monodon } \\
\hline Injection & Negative/Negative & Positive (1-step, 5/5a ) \\
\hline Per os & Not done & Positive (1- and 2-step, 3/5a) \\
\hline
\end{tabular}


sion no. EF137180) was selected for generation of a probe for in situ hybridization (ISH). The gene probe was labeled with digoxigenin-11-deoxyuridine triphosphate (dUTP) (Roche) in a PCR reaction according to the manufacturer's instructions. The primers used for the labeling reaction were $P V N V 883 F\left(5^{\prime}\right.$-AACAACAACAATCGTGGGAAC-3') and PVNV883R (5'TACCAGCCTCTGACTGGAAA-3') that generated a 883 bp amplicon. Following PCR, the digoxigeninlabeled DNA probe was precipitated with ethanol, resuspended in water, and stored at $-20^{\circ} \mathrm{C}$.

The Davidson's AFA-fixed shrimp were processed, embedded in paraffin, and sectioned (4 $\mu$ m thick) in accordance with standard methods (Lightner 1996). After deparaffinization, hydration, Proteinase K digestion, and post-fixation, sections were overlaid with $250 \mu \mathrm{l}$ of hybridization solution $(4 \times \mathrm{SSC}, 50 \%$ formamide, $1 \times$ Denhardt's solution, $5 \%$ dextran sulfate, $0.5 \mu \mathrm{g} \mathrm{ml}^{-1}$ salmon sperm DNA) containing the PVNV probe $\left(0.2 \mu \mathrm{g} \mathrm{ml}^{-1}\right)$, and hybridized overnight at $42^{\circ} \mathrm{C}$. Final detection was performed with anti-digoxigenin antibody conjugated to alkaline phosphatase (Roche) that was visualized using nitroblue tetrazolium and 5bromo-4-chloro-3-indolyl phosphate.

Nested RT-PCR. Total RNA was extracted from tissues (pleopods or head soft tissues) or hemolymph of shrimp using the TRIzol reagent (or TRIzol LS for hemolymph samples) (Invitrogen). The SuperScript III 1-step RT-PCR system with Platinum Taq DNA polymerase (Invitrogen) was used for RT-PCR. The extracted RNA was reverse transcribed at $55^{\circ} \mathrm{C}$ for $30 \mathrm{~min}$ and the PCR was initiated at $94^{\circ} \mathrm{C}$ for $2 \mathrm{~min}$, followed by 40 cycles of $94^{\circ} \mathrm{C}$ for $15 \mathrm{~s}, 55^{\circ} \mathrm{C}$ for $30 \mathrm{~s}$, and $68^{\circ} \mathrm{C}$ for $30 \mathrm{~s}$, ending with $68^{\circ} \mathrm{C}$ for $5 \mathrm{~min}$. Primers used for RT-PCR were PVNV339F (5' -CTGTCTCACAGGCTGGTTCA-3') and PVNV339R (5'-CCGTTTGAATTTCAGCAACA-3'). The 1-step RT-PCR amplified a 339 bp fragment from viral genome. For the 2step PCR, PuReTaq Ready-To-Go PCR beads (Amersham Biosciences) were used. The primers for the 2-step PCR were PVNV246NF (5'-CAAAACTGTGCCTTTGATCG-3') and PvNV246NR (5'-GCCTTATCCACACGAACGTC-3'). The amplification was performed with the following cycling parameters: initial denaturation at $94^{\circ} \mathrm{C}$ for $5 \mathrm{~min}$, followed by 30 cycles of $94^{\circ} \mathrm{C}$ for $30 \mathrm{~s}, 60^{\circ} \mathrm{C}$ for $30 \mathrm{~s}$, and $72^{\circ} \mathrm{C}$ for $30 \mathrm{~s}$, and a final extension at $72^{\circ} \mathrm{C}$ for $7 \mathrm{~min}$. A $246 \mathrm{bp}$ fragment was amplified by the 2-step PCR. Following PCR, an aliquot of the PCR products was analyzed in a $1.5 \%$ agarose gel containing ethidium bromide and then photographed using an imaging system, AlphaImager (Alpha Innotech).

\section{RESULTS}

\section{Histology and clinical signs of PVNV infection}

Histological examination of samples of Penaeus vannamei with white tails sent from a shrimp farm in Belize showed multifocal necrosis in the skeletal muscle accompanied by hemocytic congestion, fibrocytic inflammation, and phagocytosis (Fig. 1A). Basophilic inclusions were found within the muscle fibers (Fig. 1B) and in the lymphoid organ (Fig. 1C). In addition, lymphoid organ spheroids were observed. The major histopathological characteristics presented by these Belize shrimp were very similar to those associated with infection by IMNV. However, we carried out ISH and RT-PCR with the Davidson's fixed and alcohol preserved samples, and IMNV was not detected.

To determine whether another infectious agent was causing the IMNV-like muscle necrosis, an inoculum was prepared from the frozen samples and injected into SPF Penaeus vannamei in a laboratory bioassay. At Day 14 after injection, the shrimp showed white, opaque lesions in the tail muscle (Fig. 2). Histo-

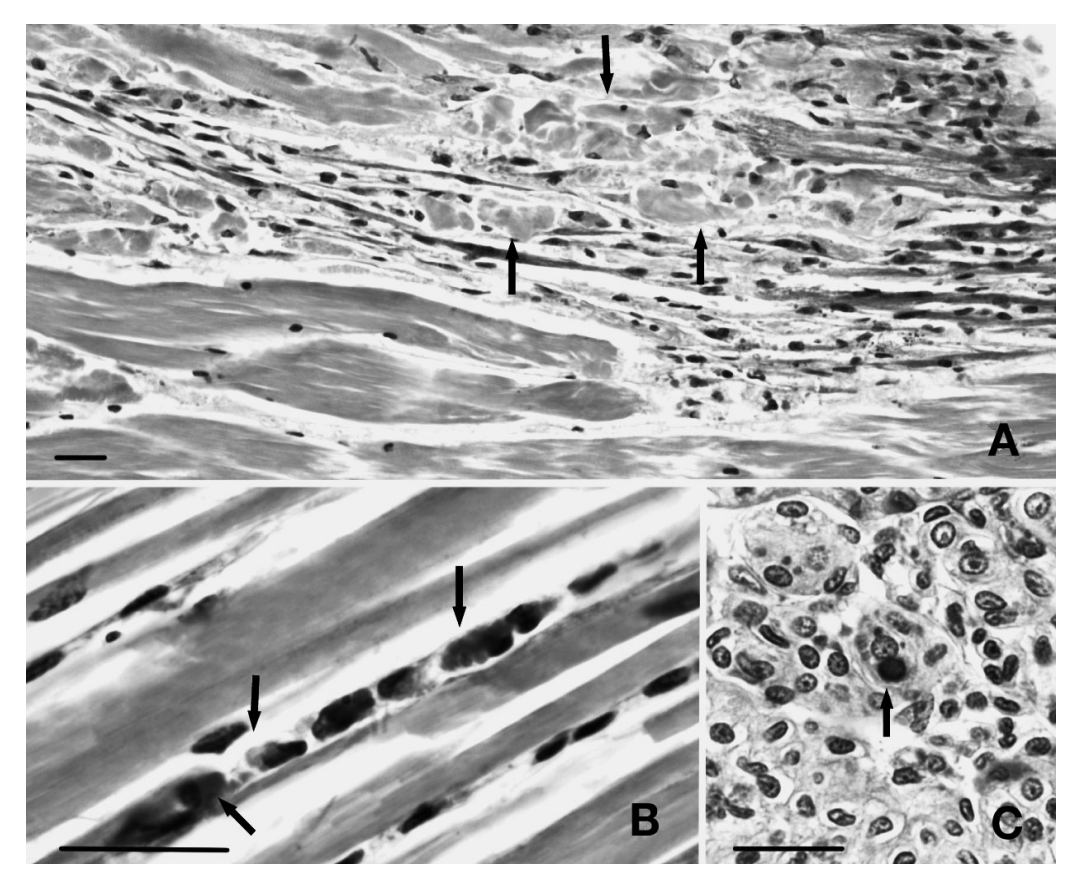

Fig. 1. Penaeus vannamei. Histological examination of specimens collected from a farm in Belize. (A) H\&E (Mayer-Bennet haematoxylin and eosinphloxine) staining of muscle necrosis (arrows) in the tail. Basophilic inclusions (arrows) were found in the (B) striated muscle and (C) lymphoid organ. Scale bars $=25 \mu \mathrm{m}$ 
logical examination confirmed the presence of muscle necrosis and lymphoid organ spheroids, indicating that the muscle necrosis was caused by an infectious agent.

\section{Ultrastructure of $P V N V$}

Transmission electron microscopy examination of the lymphoid organ sections from the infected Penaeus vannamei showed the presence of intracytoplasmic inclusions with paracrystalline arrays of the virus particles (Fig. 3). These particles are nodaviruslike and approximately $22 \mathrm{~nm}(\mathrm{n}=20)$ in diameter.

\section{Cloning of $P V N V$ genomic cDNA}

The presence of intracytoplasmic inclusions suggested that this agent may be a RNA virus. We constructed a cDNA library from RNA extracted from the hemolymph of infected shrimp. One clone (designated as $P V N V-4)$ containing a 928 bp insert was sequenced and analyzed using Blastn at the National Center for Biotechnology Information (NCBI) web site (www.ncbi.nlm.nih.gov/blast), but no significant matches were found. However, a search with Blastp found that the translated amino acid sequence (243 out of the 309 aa) had a $69 \%$ similarity and an expect value (E) of $2 \times 10^{-65}$ to the amino acid sequence of MrNV (GenBank NP_919038) (Fig. 4). This result

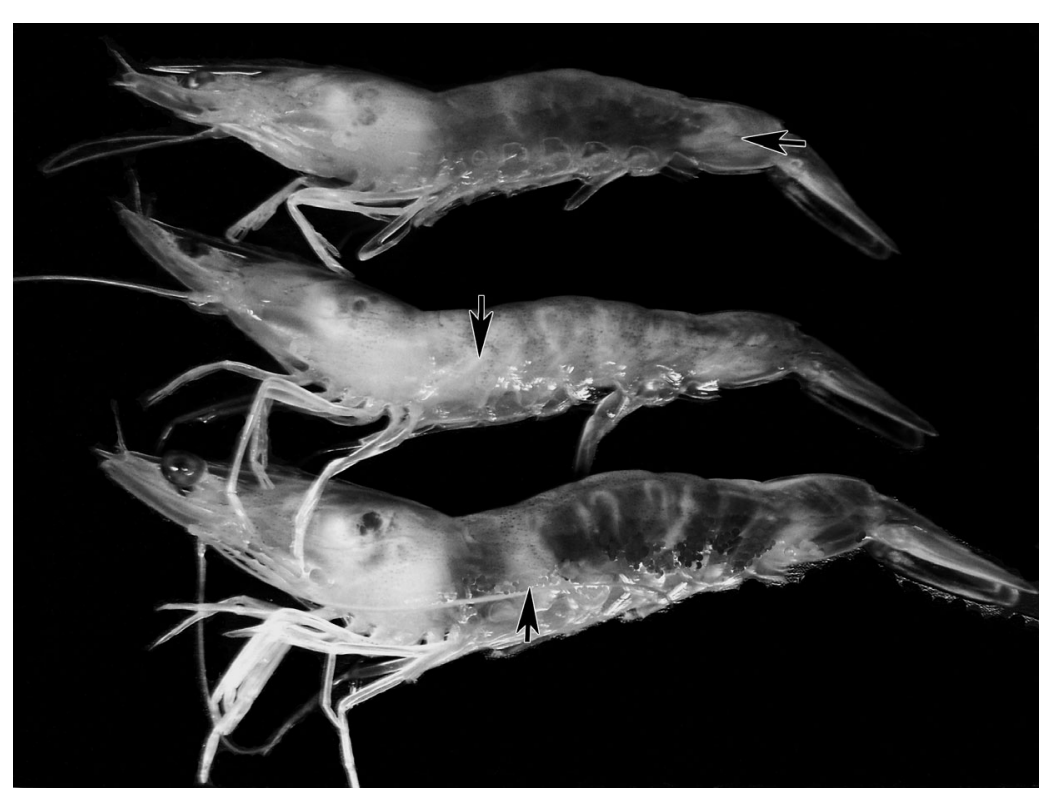

Fig. 2. Penaeus vannamei. Gross signs of $P$. vannamei nodavirus (PvNV)infected shrimp. White, opaque lesions (arrows) in the tail

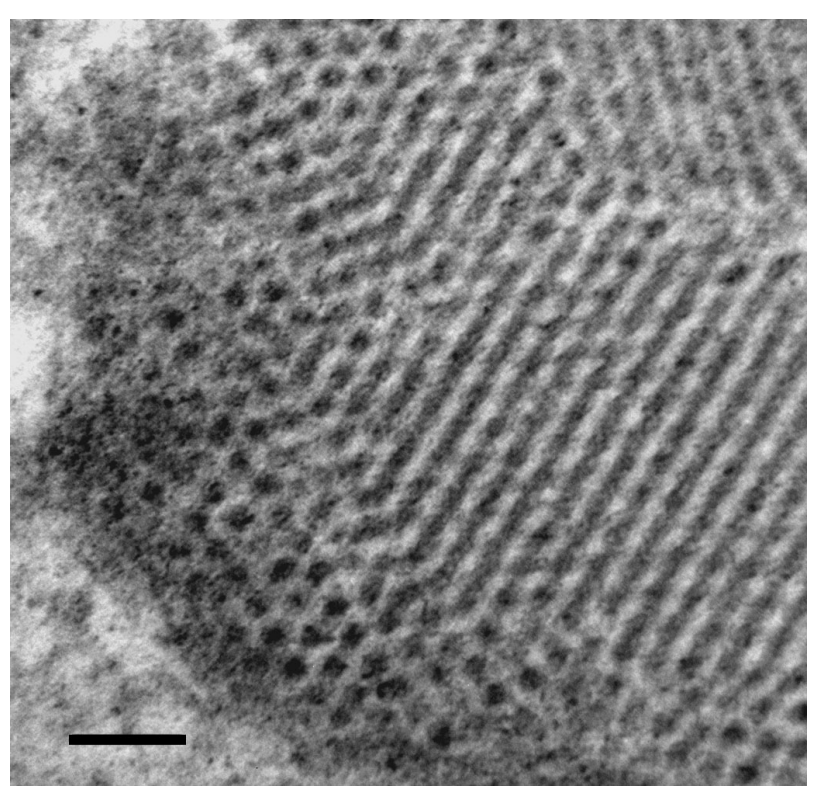

Fig. 3. Penaeus vannamei. Electron microscope image of paracrystalline arrays of $P V N V$ particles in shrimp lymphoid organ tissue. Scale bar $=100 \mathrm{~nm}$

indicated that the Belize agent was most likely a nodavirus, and it was tentatively named $P V N V$. The viral insert contained in the $P V N V-4$ clone was located within the capsid protein-coding region.

\section{In situ hybridization of $P v N V$}

The insert of $P v N V-4$ was labeled with digoxigenin and used to detect $P V N V$ in situ in the infected Penaeus vannamei generated from the laboratory bioassays. Basophilic inclusions were found in the connective tissues (Fig. 5A), which reacted intensely to the probe (Fig. 5B). The probe appears to be highly specific. No reaction was seen in any of the tissues prepared from healthy, uninfected shrimp or from those infected with IMNV, white spot syndrome virus (WSSV), infectious hypodermal and hematopoietic necrosis virus (IHHNV), Taura syndrome virus (TSV), or yellow head virus (YHV). Other tissues reacting to the probe included the lymphoid organ, heart, gills, and skeletal muscle in the tail (Fig. 5C-F). In lymphoid organ tubules (Fig. 5C), the probe reacted most intensely in the outermost layer of stromal matrix cells; the central endothe- 
PVNV : APLQALTSYSRPNVNKISRTGPDSDFLTSVVAKASTSIVTPADRILVKQPISASSFPGTRIT
MrNV : APLQTNIRSARSDVNAITVLN-GSDFLTVKVRGSNNLTDSKSRILVKOPISASSFLGTRIS

PVNV : GLSSYWERYKWLAVARYVPAVPNTVACOFVMYIDTDPLDDP SNISDDNOIVRQAVSOAGSN

MrNV : GLSQFWERYRWHKA ARYVPAVPNTLACOLIGYIDTDPLDDPNVILDVDQLLRQA TSOVGAR

PVNV : QFNFNTSKIVPLIVRADNQYYYTEVDKQNLRFSLQGILYIIQVTDIINFNGELITQDLTCGS

MrNV : OWNFSDTIIPLIVRRDDQLYYTGQDKENVRFSQOGVFYLLQVTTLLNISGEAITNDLISGS

PVNV : LFLDWIVNFSIPQINPT- - -SLTDVRVDKAVNFIKPEVSGVAEIOTVTGISPSTSYLITE

MrNV : LYLDWVCGFSMPQINPTPVEVSQLTYNADTIGNWVPPTELKQIYTQDITGLKPNSKFIIVP

Fig. 4. Alignment of the translated amino acid sequence of PvNV-4 to the sequence of capsid protein of Macrobrachium rosenbergii nodavirus ( $\mathrm{MrNV}$ ). Identical and similar amino acids are shaded; dashes (- - -) indicate the gaps

lial and surrounding stromal matrix cells were not reactive. In heart tissue (Fig. 5D), ISH signals were found in fixed phagocytes but not in cardiac muscle. In gill tissues (Fig. 5E), the reactive sites were in the afferent/efferent vessels; no signal was detected in the epithelial cells. For skeletal muscle (Fig. 5F), the signals were very strong and often diffusely distributed within the muscle fibers.

The PVNV ISH was also used to confirm the PVNVinfection in shrimp samples collected from the affected Belize farm. In 5 representative samples collected in 2004 and 2005, skeletal muscle had the most pronounced reaction. The tissues reacting to the probe were the same as those found in the laboratoryinfected shrimp.

\section{Experimental infection and PVNV RT-PCR assay}

By laboratory injection and per os challenge, both Penaeus monodon and P. vannamei were susceptible to $P V N V$ infection. After injection, $50 \%$ of the $P$. vannamei showed white tails by Day 11 post-injection, but there were no mortalities throughout the $4 \mathrm{wk}$ bioassay. Histological examination and ISH confirmed skeletal muscle necrosis (Table 1). Injected $P$. monodon did not display white tails or muscle necrosis. Although ISH tests were also negative, PVNV was detected by RT-PCR (see below).

A nested RT-PCR assay showed that Penaeus monodon and $P$. vannamei were infected with $P V N V$ from either injection or per os exposure (Fig. 6, Table 1). In the injection challenges, samples from each species were all strongly positive after the 1-step of RT-PCR (Fig. 6, lanes 1 and 2). The shrimp from the per os exposure showed much weaker RT-PCR reactions (Fig. 6, lanes 3 and 5). Stronger bands were observed after the 2-step PCR (Fig. 6, lanes 4 and 6). In the per os challenge, only 3 out of 5 sampled shrimp from each species were positive (Table 1). No mortality was observed in per os challenge bioassays with either species.

In the time-course study with Penaeus monodon, PVNV was detected $2 \mathrm{~h}$ after injection, and the level decreased thereafter until Day 3 in pleopods samples and Day 5 in hemolymph samples (Fig. 6B). From these points on, the level of PvNV increased continuously until the end of experiment (Day 15).

The nested RT-PCR appeared to be specific for $P V N V$, because it did not cross react with either IMNV, YHV, or TSV. In infected shrimp, PVNV was detected in RNA extracted from various tissues including pleopods, head soft tissues, and hemolymph.

\section{DISCUSSION}

White tail disease in penaeid shrimp can be caused by either IMNV or PVNV. Both viruses target primarily the skeletal muscle and result in very similar gross signs, namely a white or opaque tail. Histologically, the diseases are almost indistinguishable, and both are characterized by muscle necrosis and the formation of prominent lymphoid organ spheroids. However, there is a difference in the mortality caused by these 2 viruses. PVNV appeared to be less virulent than IMNV, which causes $20 \%$ mortality in laboratory-infected Penaeus vannamei (Tang et al. 2005). In contrast, $P V N V$ did not cause mortality in $P$. vannamei in laboratory infections. Our results also showed that $P V N V$ infection was not found in all the per os challenged shrimp; only 3 out of 5 shrimp tested positive by nested RT-PCR. It may be that $P V N V$ is a slowly replicating virus, and hence, a $4 \mathrm{wk}$ bioassay period 


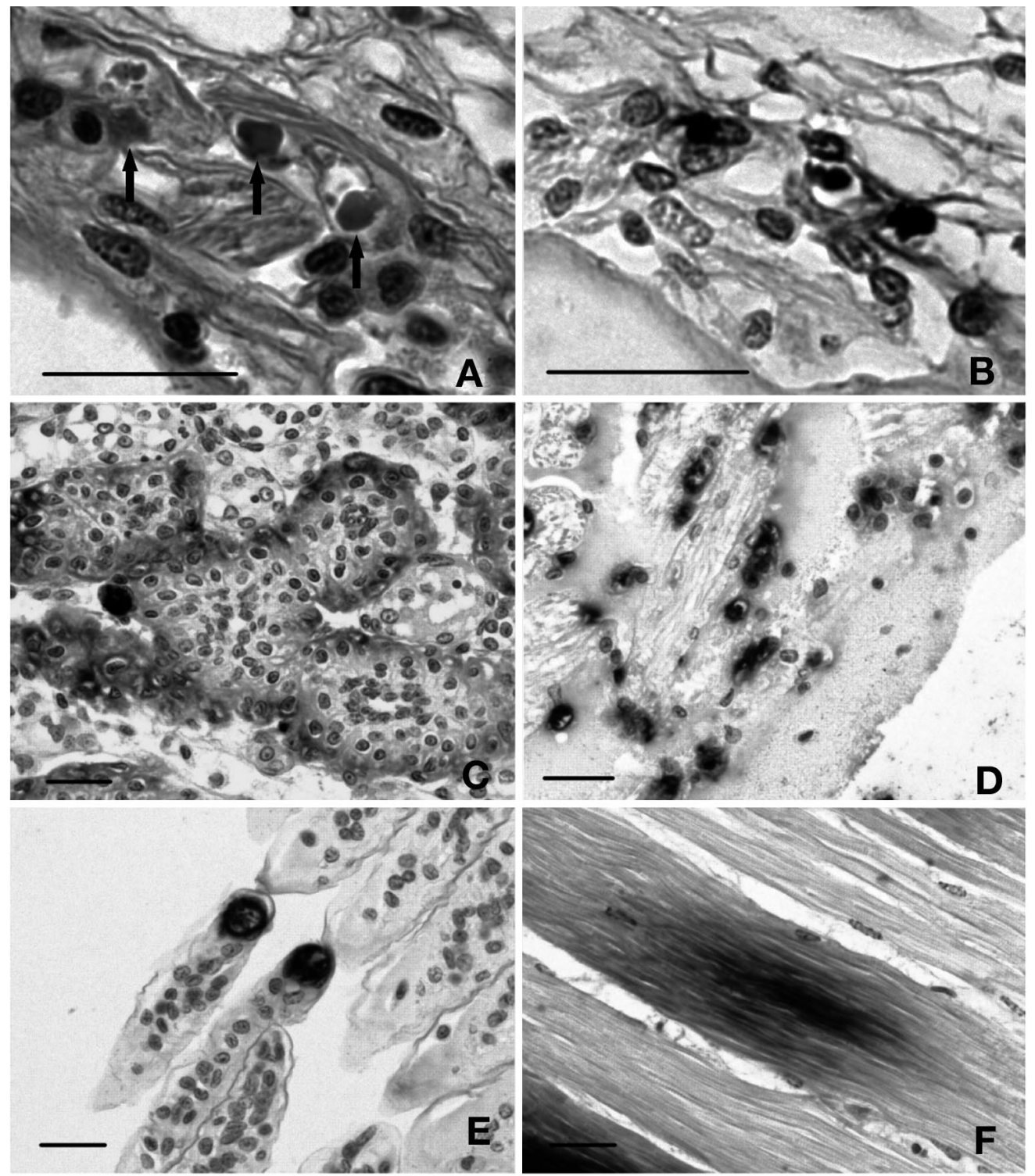

Fig. 5. Penaeus vannamei. H\&E (Mayer-Bennet haematoxylin and eosin-phloxine) histology and in situ hybridization of $P V N V$ in infected shrimp. (A) H\&E staining of connective tissue of the serosal layer of the anterior midgut caecum. Arrows indicate cytoplasmic inclusions. (B) In situ hybridization of the consecutive section with a digoxigenin-labeled PvNV probe. In situ hybridization of $P_{V N V}$ in the (C) lymphoid organ, (D) heart, (E) gills, (F) skeletal muscle. Scale bars $=25 \mu \mathrm{m}$

may not be sufficient for the infection to reach a level that can be detected by nested RT-PCR. Nevertheless, higher levels of PVNV infection can be found in farm samples, as in the 5 representative samples that tested positive by in situ hybridization. These shrimp were larger (over $10 \mathrm{~g}$ ), and it is likely that they had been infected with $P V N V$ for a longer period of time. For $P$. monodon, the time-course study showed an increasing level of $P_{V N V} 5 \mathrm{~d}$ after injection throughout the bioassay, indicating that $P_{V N V}$ was replicating in $P$. monodon. The PVNV present in the inoculum was decreasing by Days 3 to 5 ; the RT-PCR signals detected at Days 10, 15, and 30 after injection were not from the inoculum.

White tail disease found in the freshwater prawn Macrobrachium rosenbergii is caused by $M r N V$, a nodavirus. $P V N V$ is related to $M r N V$ based on the similarity of their genome sequences and in histopathology. MrNV was first discovered in Guadeloupe in 1997 (Arcier et al. 1999) and was later found in China, India and Thailand (Qian et al. 2003, Sahul Hameed et al. 2004a, Yonganandhan et al. 2006). MrNV can cause severe mortality (up to $100 \%$ ) in the post-larval and juvenile stages of freshwater prawns. $\mathrm{MrNV}$ is associ- 

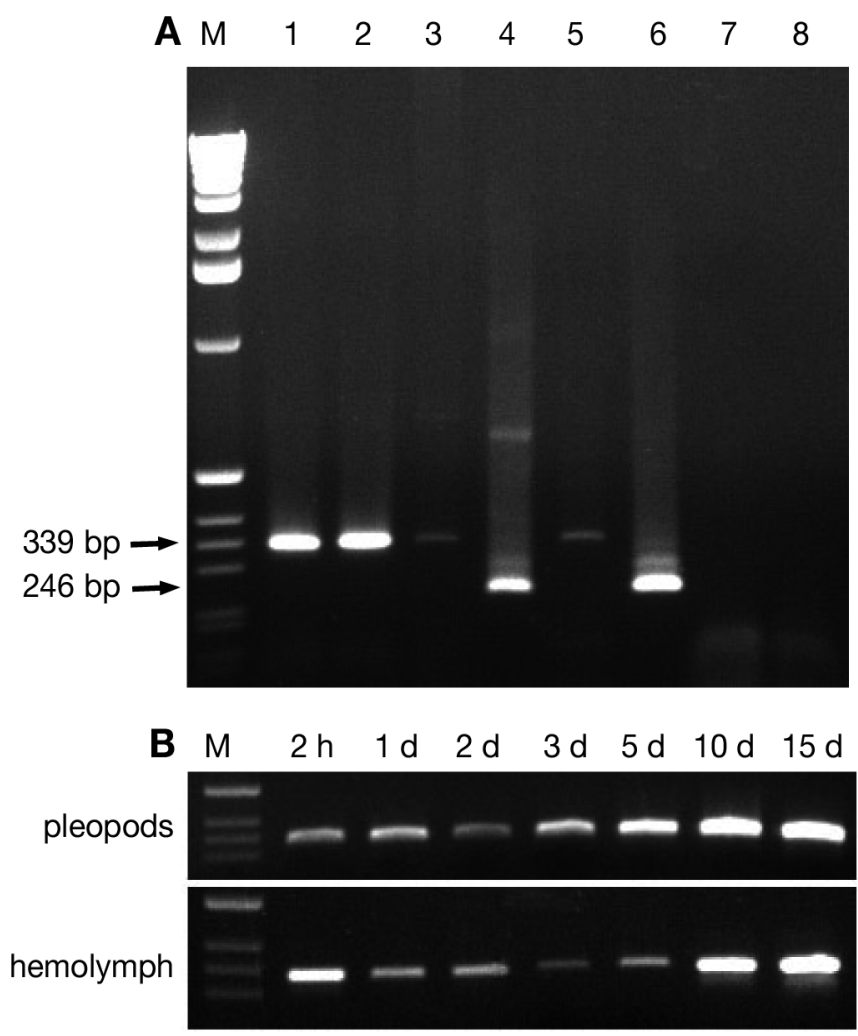

Fig. 6. Penaeus vannamei and P. monodon. (A) RT-PCR detection of $P V N V$ in laboratory-infected shrimp. M: $1 \mathrm{~kb}$ ladder molecular weight marker. RT-PCR assay of shrimp collected 4 wk after injection in $P$. vannamei (lane 1) and in P. monodon (lane 2). Nested RT-PCR assay of shrimp collected $4 \mathrm{wk}$ after per os exposure in $P$. vannamei (lanes 3 and 4, 1- and 2-step, respectively) and in P. monodon (lanes 5 and 6, 1- and 2-step, respectively). Lane 7: non-template control; lane 8: RNA template extracted from specific-pathogen-free shrimp. (B) RTPCR detection of $P V N V$ in a time-course study of $P$. monodon. $\mathrm{M}$ : molecular weight marker. Lanes $2 \mathrm{~h}$ to $15 \mathrm{~d}$ : RT-PCR products of $P V N V$, samples (upper panel: pleopods; lower panel: hemolymph) taken at $2 \mathrm{~h}$, and Days 1, 2, 3, 5, 10 and 15 after injection, respectively. Only the 1 -step RT-PCR was performed

ated with a satellite virus XSV (extra small virus) (Qian et al. 2003, Sri Widada \& Bonami 2004). But the role of $\mathrm{XSV}$ in the white tail disease is not clear. $M r N V$ and associated XSV can infect adult $M$. rosenbergii, but in adults, it does not cause mortality (Sahul Hameed et al. 2004b).

Although PvNV did not cause mortality in the laboratory bioassays, it appears to affect survival in growout ponds. PVNV-related mortality is sporadic, often associated with environmental stress, such as crowding and high temperature. When the shrimp are stocked at a high density $\left(>50 \mathrm{~m}^{-2}\right)$, or when the temperature is $>32^{\circ} \mathrm{C}$, survival in $P V N V$-infected ponds decreases to $40 \%$, with an increase of the food conversion ratio from means of around 1.50 to 3.63. In one
Belize farm, survival was reduced from an average of $74 \%$ in 2003 (before $P v N V$ was detected) to $50 \%$ after the appearance of $P V N V$ in 2004 (i.e. an estimated $50 \%$ production loss for the infected farm). If the infection is not monitored, it may lead to spread of $P V N V$ to other farms or countries, and could result in significant production losses in those areas.

Here we report the development of 2 methods for the detection of $P v N V$, viz. ISH and nested RT-PCR. The ISH method can be used to distinguish between $P V N V$ and IMNV infections, because the respective probes are not cross-reactive. The nested RT-PCR can be used as a routine diagnostic tool to detect $P V N V$ infection that does not cause severe mortality in Penaeus vannamei, or where there are no clinical signs or histological lesions, as in the case of infections in P. monodon.

Acknowledgements. This work was supported by Gulf Coast Research Laboratory Consortium Marine Shrimp Farming Program, USDA. We thank the anonymous shrimp grower in Belize for providing the PVNV-infected shrimp samples, Moana Technologies, LLC for providing SPF Penaeus monodon for laboratory bioassays, and B. Noble for providing assistance in bioassays.

\section{LITERATURE CITED}

Arcier JM, Herman F, Lightner DV, Redman RM, Mari J, Bonami JR (1999) A viral disease associated with mortalities in hatchery-reared postlarvae of the giant freshwater prawn Macrobrachium rosenbergii. Dis Aquat Org 38: 177-181

Bell TA, Lightner DV (1988) A handbook of normal penaeid shrimp histology. World Aquaculture Society, Baton Rouge, LA

Bonami JR, Lightner DV, Redman RM, Poulos BT (1992) Partial characterization of a togavirus (LOVV) associated with histopathological changes of the lymphoid organ of penaeid shrimps. Dis Aquat Org 14:145-152

Bonami JR, Shi Z, Qian D, Sri Widada J (2005) White tail disease of the giant freshwater prawn Macrobrachium rosenbergii: separation of the associated virions and characterization of MrNV as a new type of nodavirus. J Fish Dis 28:23-31

Holthius LB (1980) Shrimps and prawns of the world: an annotated catalogue of species of interest to fisheries. FAO species catalogue: FAO fisheries Synopsis 125(1). Food and Agricultural Organization of the United Nations, Rome

Lightner DV (1988) Muscle necrosis of penaeid shrimp. In: Sindermann CJ, Lightner DV (eds) Disease diagnosis and control in north America marine aquaculture. Developments in aquaculture and fisheries science, Vol 17. Elsevier Press, New York, p 122-124

Lightner DV (1996) A handbook of shrimp pathology and diagnostic procedures for diseases of cultured penaeid shrimp. World Aquaculture Society, Baton Rouge, LA

Nunes AJP, Martins PCC, Gesteira TCV (2004) Carcinicultura ameaçada: produtores sofrem com mortalidades do virus da mionecrose infeccisa (IMNV). Panorama Aquicultura 14:37-51 (in Portuguese)

Poulos BT, Tang KFJ, Pantoja CR, Bonami JR, Lightner DV (2006) Purification and characterization of infectious 
myonecrosis virus of penaeid shrimp. J Gen Virol 87: 987-996

Qian D, Shi Z, Zhang S, Cao Z and 5 others (2003) Extra small virus-like particles (XSV) and nodavirus associated with whitish muscle disease in the giant fresh water prawn Macrobrachium rosenbergii. J Fish Dis 26: 521-527

Sahul Hameed AS, Yoganandhan K, Sri Widada J, Bonami JR (2004a) Studies on the occurrence of Macrobrachium rosenbergii nodavirus ( $\mathrm{MrNV}$ ) and extra small virus-like particles (XSV) associated with white tail disease (WTD) of Macrobrachium rosenbergii in India by RT-PCR detection. Aquaculture 238:127-133

Sahul Hameed AS, Yoganandhan K, Sri Widada J, Bonami JR (2004b) Experimental transmission and tissue tropism of Macrobrachium rosenbergii nodavirus ( $\mathrm{MrNV}$ ) and its associated extra small virus (XSV). Dis Aquat Org 62: 191-196

Shekhar MS, Azad IS, Jithendran KP (2006) RT-PCR and sequence analysis of Macrobrachium rosenbergii nodavirus: Indian isolate. Aquaculture 252:128-132

Editorial responsibility: Timothy Flegel,

Bangkok, Thailand
Sri Widada J, Bonami JR (2004) Characteristics of the monocistronic genome of extra small virus, a virus-like particle associated with Macrobrachium rosenbergii nodavirus: possible candidate for a new species of satellite virus. J Gen Virol 85:643-646

Tang KFJ, Pantoja CR, Poulos BT, Redman RM, Lightner DV (2005) In situ hybridization demonstrates that Penaeus vannamei, L. stylirostris and Penaeus monodon are susceptible to experimental infection with infectious myonecrosis virus (IMNV). Dis Aquat Org 63:261-265

Wyban JA, Swingle JS, Sweeney JN, Pruder GD (1992) Development and commercial performance of high health shrimp using specific pathogen free (SPF) broodstock Penaeus vannamei. In: Wyban J (ed) Proceedings of the Special Session on Shrimp Farming at Aquaculture '92. World Aquaculture Society, Baton Rouge, LA, p 254-259

Yonganandhan K, Leartvibhas $M$, Sriwongpuk S, Limsuwan C (2006) White tail disease of the giant freshwater prawn Macrobrachium rosenbergii in Thailand. Dis Aquat Org 69:255-258

Submitted: September 18, 2006; Accepted: February 2, 2007 Proofs received from author(s): April 11, 2007 